\title{
Impact of Natural Compounds on DNA Methylation Levels of the Tumor Suppressor Gene RASSF1A in Cancer
}

\author{
Reinhard H. Dammann ${ }^{1,2, *}$, Antje M. Richter ${ }^{1}$, Adriana P. Jiménez ${ }^{1}$, Michelle Woods ${ }^{1}$, \\ Miriam Küster ${ }^{1}$ and Chamindri Witharana ${ }^{3}$ \\ 1 Institute for Genetics, Justus-Liebig-University Giessen, D-35392 Giessen, Germany; \\ antje.m.richter@gen.bio.uni-giessen.de (A.M.R.); adriana.jimenez@gen.bio.uni-giessen.de (A.P.J.); \\ michelle.woods@bio.uni-giessen.de (M.W.); miriam.kuester@gen.bio.uni-giessen.de (M.K.) \\ 2 German Center for Lung Research (DZL), Universities of Giessen and Marburg Lung Center, \\ D-35392 Giessen, Germany \\ 3 Department of Biochemistry and Molecular Biology, Faculty of Medicine, University of Colombo, \\ Colombo 0080, Sri Lanka; chamindri@bmb.cmb.ac.lk \\ * Correspondence: reinhard.dammann@gen.bio.uni-giessen.de; Tel.: +49-641-993-5462; Fax: +49-641-993-5469
}

Received: 1 September 2017; Accepted: 12 October 2017; Published: 17 October 2017

\begin{abstract}
Epigenetic inactivation of tumor suppressor genes (TSG) is a fundamental event in the pathogenesis of human cancer. This silencing is accomplished by aberrant chromatin modifications including DNA hypermethylation of the gene promoter. One of the most frequently hypermethylated TSG in human cancer is the Ras Association Domain Family 1A (RASSF1A) gene. Aberrant methylation of RASSF1A has been reported in melanoma, sarcoma and carcinoma of different tissues. RASSF1A hypermethylation has been correlated with tumor progression and poor prognosis. Reactivation of epigenetically silenced TSG has been suggested as a therapy in cancer treatment. In particular, natural compounds isolated from herbal extracts have been tested for their capacity to induce RASSF1A in cancer cells, through demethylation. Here, we review the treatment of cancer cells with natural supplements (e.g., methyl donors, vitamins and polyphenols) that have been utilized to revert or prevent the epigenetic silencing of RASSF1A. Moreover, we specify pathways that were involved in $R A S S F 1 A$ reactivation. Several of these compounds (e.g., reseveratol and curcumin) act by inhibiting the activity or expression of DNA methyltransferases and reactive RASSF1A in cancer. Thus natural compounds could serve as important agents in tumor prevention or cancer therapy. However, the exact epigenetic reactivation mechanism is still under investigation.
\end{abstract}

Keywords: DNA methylation; tumor suppressor gene; RASSF1; demethylation; natural compounds

\section{Introduction}

DNA methylation is an important epigenetic modification in mammalians and occurs predominately at $\mathrm{CpG}$ dinucleotides in the genome. At $\mathrm{CpG}$ sites, cytosine is modified by an enzyme called DNA methyltransferase (DNMT) and a methyl group is added at the 5-position. De novo methylation is catalyzed by DNMT3A and DNMT3B. In double-stranded DNA, methylated CpGs are short palindromic sequences, and methyl groups which are located in the large grove of the double helix are recognized by methyl-CpG binding domain-containing proteins (e.g., MBD2). These proteins recruit chromatin silencing complexes that result in condensation of the chromosomal region. During semi-conservative DNA replication, unmethylated CpGs on the newly synthesized daughter strand are methylated by DNMT1. This maintenance DNA methyltransferase is recruited to the hemi-methylated CpG sequences with the help of several co-factors including PCNA and UHRF1 [1,2]. 
In mammalians $\mathrm{CpG}$ and GC-rich regions, so-called $\mathrm{CpG}$ islands are often localized at regulatory regions like gene promoters and imprinting centers. Unmethylated $\mathrm{CpG}$ island promoters are in an open chromatin configuration and are correlated with active gene transcription. However, hypermethylated $\mathrm{CPG}$ islands consist of epigenetic inactive chromatin regions. During aging and carcinogenesis, several $\mathrm{CpG}$ island promoters become aberrantly methylated. Hypermethylation of tumor suppressor genes (TSG) is a hallmark of their inactivation in the pathogenesis of cancer. One of the most frequently hypermethylated CpG islands of a TSG is located in the promoter region of the Ras Association Domain Family 1A (RASSF1A) gene [3,4].

\section{The Ras Association Domain Family 1 (RASSF1) Gene}

In lung cancer, deletion of a region in 3p21.3 of chromosome 3 has frequently been reported [5]. Chromosomal deletions of this region have also been found in other cancer entities (in tissues of e.g., breast, head and neck, kidney and gastrointestinal tract) [6]. In the minimal deletion region, we and others have discovered the Ras Association Domain Family 1 gene (Figure 1) [4,7]. Initially, we termed the gene Ras effector homologue 3p21, since its protein sequences exhibited homologies to the murine novel Ras effector 1 (Nore1) [8]. However, the HUGO gene nomenclature committee renamed it to Ras Association Domain Family 1 (RASSF1) gene and human NORE1 was later renamed RASSF5.

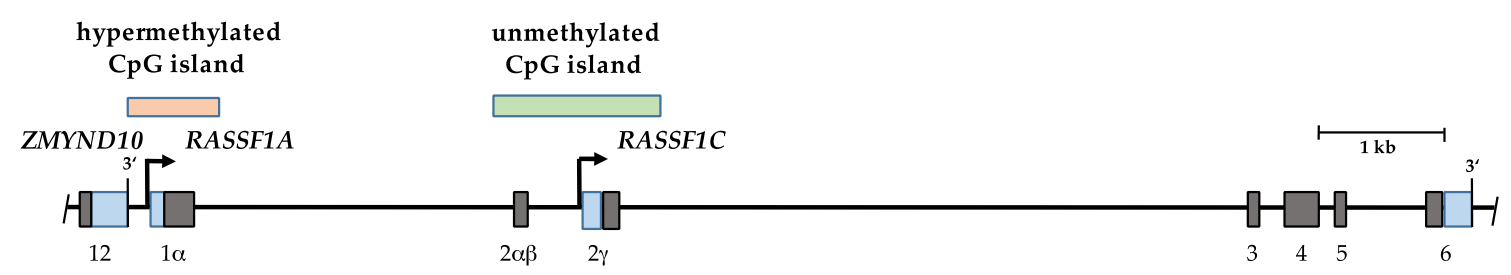

Figure 1. Genomic organization of the RASSF1 gene. $12 \mathrm{~kb}$ of the genomic region of chromosome 3p21.3 (hg19: 50,379,000-50,367,000) is shown. Exons are numbered and depicted as black and blue boxes indicating coding and untranslated regions, respectively. The RASSF1A isoform is transcribed from a CpG island containing $84 \mathrm{CpG}$ sites, that is often hypermethylated in cancer. Transcription of RASSF1C initiates a downstream located CpG island consisting of $139 \mathrm{CpGs}$. Transcription start sites are indicated with arrows and transcription end sites are marked with $3^{\prime}$. ZMYND10 represents the last exon (12) of the zinc finger MYND-type containing 10 gene, which is located $200 \mathrm{bp}$ upstream of RASSF1A promoter.

Subsequently, we identified two main isoforms of RASSF1, that were transcribed by two distinct CpG island promoters: RASSF1A and RASSF1C (Figure 1). A third variant initially named RASSF1B was only expressed at very low levels, and its biological function was not further investigated [4]. The transcript of RASSF1A contains six exons $(1 \alpha, 2 \alpha \beta, 3,4,5$ and 6$)$ and is translated to a protein with 340 aa (Figure 2). The RASSF1C variant is transcribed from an intragenic CpG island and consists of 5 exons $(2 \gamma, 3,4,5$ and 6). On protein level, RASSF1A and RASSF1C both encode a C-terminal Ras Association domain (RA) (Figure 2). The rat sarcoma genes (Ras) are a family of small GTPases that function as proto-oncogenes by regulating mitogen-induced signaling pathways. In contrast to RASSF5/NORE1, which interacts with several Ras proteins, the direct interaction of RASSF1 with Ras proteins is rather weak [9]. Most likely, the interaction of RASSF1A with Ras is indirect through binding to the endogenous RASSF5 [9]. The RA domain of RASSF1 is also defined as an ubiquitin-like domain (UBQ) [10]. A domain that is only present in the RASSF1A protein is the protein kinase C conserved region 1 (C1) (Figure 2). The $\mathrm{C} 1$ domain has been characterized as a binding site for phorbol esters and diacylglycerol, which act as tumor promoters [4].

The RASSF1 isoforms and RASSF5 encode a C-terminal SARAH (Sav/Rassf/Hpo) domain that is a characteristic coiled-coil structure (Figure 2). It is a small helical module that is important in signal-transduction networks and serves for protein-protein interactions [11]. This SARAH domain is also found in the regulatory protein WW45 (human homologue of the Drosophila protein Salvador/Sav) and the serine/threonine kinase STK3 and STK4 (human homologues of the Drosophila kinase Hippo/hpo) [11-13]. STK3 and STK4 are also often termed MST1 and MST2 (mammalian STE20-like protein kinase), 
respectively. Mutation in the Drosophila Hpo gene leads to organ overgrowth which was termed the hippopotamus (Hippo) phenotype [14]. In mammals MST1/2 kinases regulate the Hippo pathway through phosphorylation of the large tumor suppressor kinases (LATS) which in turn phosphorylate the transcriptional regulator YAP1 (Yes-associated protein 1) [15]. YAP1 was initially characterized as a protein that interacts with the src-family tyrosine kinase YES1 (homologue of the Yamaguchi sarcoma viral oncogene) and acts as a proto-oncogene [16,17]. Deregulation of the Hippo pathway results in tissue overgrowth and cancer in mammalians. In this signaling network, RASSF1A acts as an upstream activator through its interaction with MST1/2 and WW45 [13,18]. RASSF1A is the only tumor suppressor gene that is frequently inactivated in this pathway [19-21]. Thus reexpression of RASSF1A induces cell cycle arrest [22,23] and also activates the YAP1 target gene ANKRD1 [19]. Activation of ANKRD1 was absent in HeLa cells that harbor an unmethylated RASSF1A promoter and express RASSF1A [19].

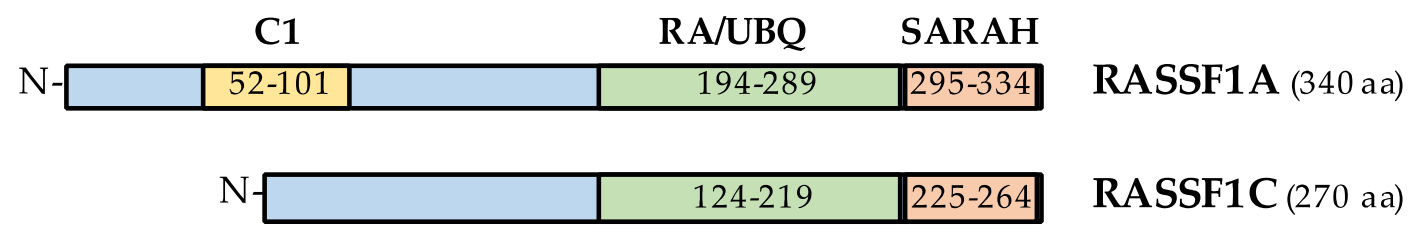

Figure 2. Protein domains of RASSF1A and RASSF1C. RASSF1A is a 340 amino acid (aa) long protein with a protein kinase $C$ conserved region (C1), Ras association/ubiquitin-like (RA/UBQ) domain and Sav/Rassf/Hpo (SARAH) domain. RASSF1C is a 270 aa long protein and encodes a RA/UBQ and a SARAH domain.

\section{Hypermethylation of RASSF1A in Human Cancers}

Initially, we observed that the RASSF1A CPG island promoter is frequently hypermethylated in lung cancer [4]. Hypermethylation of RASSF1A was revealed not only in non-small cell lung cancer but also in small cell lung cancer [4,24-26]. Interestingly, aberrant methylation of the RASSF1C CpG island promoter was not observed [4,24]. During the last two decades, it turned out that RASSF1A is frequently inactivated in all types of human cancers and promoter methylation of RASSF1A has been revealed in cancers from breast [27], liver [28], pancreas [29], prostate [30], renal cell [31,32], brain [33], gastric [34], head and neck [20], pheochromocytoma [35], thyroid [36] and others [31,37,38]. RASSF1A hypermethylation is also found in skin cancers including melanoma and Merkel cell carcinoma [39-41]. Hypermethylation of RASSF1A has been also observed in osteosarcoma and soft tissue sarcomas [42,43]. However, in other cancer entities like cervix carcinoma and colon carcinoma RASSF1A hypermethylation is also present but less frequent $(<20 \%)[31,44]$. In blood cancer, $R A S S F 1 A$ hypermethylation was frequently found in Hodkin's lymphoma, but was not revealed in chronic myeloid leukemia [45,46]. Interestingly, RASSF1A hypermethylation has been correlated with different hallmarks of advanced pathogenesis of cancer, for example with increased progression, advanced staging or metastatic properties $[36,47,48]$. It has also been reported that RASSF1A methylation correlated with a poorer prognosis of cancer patients [42,48]. It has been suggested that RASSF1A is one of the most frequently hypermethylated tumor suppressor genes in human cancers and may serve as biomarker for cancer detection [48,49].

Interestingly, we found that normal human mammary epithelial cells, when grown in cell culture for several passages, displayed a senescence-associated hypermethylation of the RASSF1A promoter [50]. This indicates that the RASSF1A promoter is susceptible to its epigenetic silencing. Recently, we revealed that for tandem-oriented genes, the downstream gene is significantly higher methylated when the transcriptional end site of the upstream gene is in proximity $(<1 \mathrm{~kb}$ distance) with the transcriptional start site [51]. The RASSF1A promoter is located only $200 \mathrm{bp}$ downstream of the last exon of the ZMYND10 gene (Figure 1). ZYMND10 encodes a protein containing a MYND-type zinc finger domain, that likely functions in assembly of the dynein motor [52]. In lung cancer, we observed a hypomethylation of the ZYMND10 promoter and increased expression of its transcript [51]. This data suggest that through its genomic organization RASSF1A is prone to epigenetic silencing. Additionally, 
in cancer we and others observed that aberrant expression of DNMT1, DNMT3A, DNMT3B and histone deacetylases (HDAC) is involved in the inactivation process of RASSF1A [51,53-56].

\section{Demethylation of RASSF1A by Treatment of Cancer Cells with Cytidine Analogues}

In contrast to mutated tumor suppressor genes that express aberrant proteins, epigenetically silenced genes are rather infrequently mutated and their reactivation has been postulated as a cure for cancer malignancies $[57,58]$. Thus, different inhibitors of DNA methylation have been tested, and specifically cytidine analogues are employed in therapy for specific blood cancers $[59,60]$. In general, these synthetic analogues lead to passive demethylation by inhibiting the methylation of the newly synthetized DNA strand during DNA replication. In contrast to cytidine, which harbors a carbon at position 5 of the base, 5-aza-cytidine and 5-aza-2'-deoxycytidine contain a nitrogen at this position and therefore cannot be methylated by DNMTs. 5-aza-cytidine (trade name: Vidaza or Azadine) and 5-aza-2'-deoxycytidine (trade name: Decitabin or Dacogen) have been approved for the treatment of the myelodysplastic syndrome and other forms of blood cancers [61,62]. Another cytidine analogue that is now in clinical trials for blood cancers is Guadecitabine (SGI-110) [63]. Guadectiabine is a 5-aza-2'-deoxycytidine and 2'-deoxyguanosine containing dinucleotide that is largely resistant to degradation by cytidine deaminase [64].

On molecular level, 5-aza-cytidine and 5-aza-2'-deoxycytidine reactivate the expression of RASSF1A in different cancer cell lines [4,32]. Usually, treatment of cancer cells for several days with 1-10 $\mu \mathrm{M}$ of 5-aza-cytidine or 5-aza-2'-deoxycytidine leads to the reexpression of the RASSF1A transcript [27]. Consistently, demethylation of the RASSF1A promoter was also observed. Treatment of an ovarian cancer cell line with $5 \mu \mathrm{M}$ SGI-110 (5-aza-2'-deoxycytidine containing dinucleotdide) for two days induced RASSF1A hypomethylation and reexpression [65]. Zebularine is yet another DNMT inhibitor and nucleoside analogue of cytidine that reactivates $R A S S F 1 A[60,66]$. It lacks the amino group at position 4 of cytidine and also inhibits cytidine deaminases [67]. A number of studies have provided evidence that several natural compounds found in food and herbs can inhibit DNMT activity or downregulate DNMT expression (Table 1) and modulate DNA methylation of tumor suppressor genes, like RASSF1A or $p 16 / C D K N A 2[68,69]$. However, there is no naturally occurring substance that function as a cytidine analogue for DNA demethylation.

Table 1. Natural compounds tested for RASSF1A reactivation in cancer.

\begin{tabular}{|c|c|c|c|c|}
\hline Compound & Effect on RASSF1A & Effect on Other Genes & Mechanism & References \\
\hline folate & $\begin{array}{c}\text { no effect [70,71], } \\
\text { increased methylation [72] }\end{array}$ & $\begin{array}{l}\text { decreased methylation of } R A R B[70,71], B R C A 1[71] \\
\text { and } C D H 1 \text { [70], increased MTHFR methylation [72] }\end{array}$ & methyl donor & [70-72] \\
\hline methionine & decreased methylation & decreased methylation of $p 16$ and MTHFR & methyl donor & [72] \\
\hline vitamin B12 & decreased methylation & increased MTHFR methylation [72] & methyl donor & {$[71,72]$} \\
\hline EGCG $^{\text {a }}$ & not analyzed & $\begin{array}{l}\text { decreased methylation of } p 16, R A R B, M G M T \text { and } \\
\text { MLH1 }\end{array}$ & $\begin{array}{l}\text { inhibits DNMT } \\
\text { activity }\end{array}$ & [73] \\
\hline reseveratol & decreased methylation & no effect on $p 16, A P C$ and $C C N D 2$ methylation & $\begin{array}{l}\text { downregulation of } \\
\text { DNMT }\end{array}$ & [74] \\
\hline curcumin & decreased methylation & decreased methylation of $R A R B$ [75] & $\begin{array}{l}\text { downregulation of } \\
\text { DNMT }\end{array}$ & [76] \\
\hline genistein & no effect & $\begin{array}{l}\text { increased methylation of RARB and CCND2 [77], } \\
\text { decreased methylation of GSTP1 and EPHB2 [78] }\end{array}$ & inhibits DNMT & {$[77,78]$} \\
\hline emodin & decreased methylation & decreased methylation of $p 16$ and $p p E N K$ & $\begin{array}{l}\text { downregulation of } \\
\text { DNMT }\end{array}$ & {$[79,80]$} \\
\hline peperomin $\mathrm{E}$ & decreased methylation & decreased methylation of $p 16, A P C$ and $R U N X 3$ & $\begin{array}{l}\text { inhibits DNMT } \\
\text { activity }\end{array}$ & [81] \\
\hline dioscin & decreased methylation & decreased methylation of $D A P K 1$ & antioxidant & [82] \\
\hline mahanine & decreased methylation & not reported & $\begin{array}{l}\text { inhibits DNMT } \\
\text { activity }\end{array}$ & [83-85] \\
\hline PEITC $^{\mathrm{c}}$ & decreased methylation & not reported & $\begin{array}{c}\text { downregulation of } \\
\text { DNMT }\end{array}$ & [86] \\
\hline
\end{tabular}

${ }^{a}$ epigalloctechin-3-gallate; ${ }^{b}$ DNA methyltransferase; ${ }^{c}$ phenethyl isothiocyanate. 


\section{Effects of Methyl Donors and Vitamins on RASSF1A Methylation}

Folate, methionine, cobalamin (vitamin B12), betaine and choline are natural compounds that serve as natural methyl donor for the DNA methylation reaction $[87,88]$. These compounds function as precursors to generate S-adenosyl-methionine (SAM) which is then used as a substrate by DNMT to methylated DNA [88]. Dietary methyl donors were shown to have epigenetic effects in mice studies which showed that high maternal intake of folic acid, vitamin B12, choline and betaine can silence a transposable element through its increased methylation [89]. In breast cancer, both positive (hypermethylation) and inverse (hypomethylation) correlations with high intake of methyl donors were observed [90].

Some of these methyl donors were studied regarding their effect on the methylation level of RASSF1A (Table 1). It has been reported that dietary folate and alcohol intake could be associated with changes in promoter hypermethylation (RASSF1A and other TSG) in patients with sporadic colorectal cancer [91]. This study indicated that folate has a protective role against promoter methylation [91]. In another study, the methylation level of a panel of ten genes including RASSF1A in blood cells of monozygotic twins with discordant smoking habits was analyzed and the methylation index was correlated with plasma levels of folic acid, vitamin B12 and homocysteine [70]. The increased methylation index of overall promoter methylation (e.g., decreased methylation of $R A R B$ and $C D H 1$ ), displayed a significant inverse correlation with plasma folic acid levels both in smokers and in non-smokers [70]. However, RASSF1A methylation levels were not significantly lower in subjects with higher plasma folic acid levels $(>4.6 \mathrm{ng} / \mathrm{mL})$ [70]. Other data for lung cancer suggested that smoking, sex, and alcohol intake had a strong influence on the methylation levels of single genes (RASSF1A and MTHFR), whereas folate intake had no significant influence on their methylation states [92]. The methylene tetrahydrofolate reductase (MTHFR) gene encodes an enzyme in the folate cycle and is important for generating the active form of folate, which is then used in the methionine cycle to synthesize the methly-donor SAM (S-adenosyl-methionine) for the DNA methylation reaction [93]. Interestingly genetic polymorphisms of MTHFR have been associated with an increased risk of cancer $[93,94]$ and hypermethylation of RASSF1A $[95,96]$. Others have investigated the effect of methionine on RASSF1A methylation levels [71,72]. Vineis et al. examined the association between DNA methylation patterns of candidate genes and the level of methionine in the blood of lung cancer patients [72]. They report that folate levels were correlated with increased methylation of RASSF1A and MTHFR, but methionine levels were associated with decreased methylation of RASSF1A [72].

Vineis et al. also analyzed vitamin Bs with the methylation of RASSF1A and other TSG. Their data suggest that increased vitamin B12 levels are correlated with a decrease of RASSF1A methylation in former smorkers [72]. In breast cancer patients, the level of dietary methyl donors was correlated with the promoter hypermethylation status of retinoic acid receptor-beta (RARB), BRCA1 and RASSF1A [71]. There was no association with nutritional intakes and RASSF1A methylation, but high dietary intake of folate increased the chance of demethylation-dependent expression of BRCA1 [71]. In another study, randomized breast cancer patients received daily supplements of co-enzyme Q10, riboflavin and niacin (vitamins B2 and B3, respectively) along with tamoxifen [97]. A significant decrease in RASSF1A methylation was found in patients treated with nutritional supplements compared to control patients [97]. The exact mechanism that regulates preferential modulations of DNA methylation levels of a specific set of genes by methyl donors and vitamin Bs in specific cancer types is still enigmatic [72]. Other vitamins that target DNMT are retinoic acid (vitamin A) [98] and cholecalciferol (vitamin D3) [99], but these were not tested for their effects on the RASSF1A methylation level in cancer cells.

\section{Impact of Naturally Occurring Polyphenols on RASSF1A Methylation}

Several natural occurring compounds are derivates of polyphenols including resveratrol, curcumin, genistein and epigalloctechin-3-gallate (EGCG) and these regulate DNMT activity or expression $[100,101]$. Some of these substances have been tested for the capacity to reactivate RASSF1A (Table 1). Scoccianti et al. have analyzed a group of smokers who were on a normal isocaloric diet or a diet enriched with flavonoids of green tea and soy products [102]. They analyzed the methylation 
level of RASSF1A and other regions (e.g., LINE1 with 72\% methylation level) in white blood cells of smokers before and after four weeks of diet. The methylation level of RASSF1A was not affected by these diets, since it was rather unmethylated. However, repetitive poly-A retrotransposons (LINE1) showed a small but significant increase (1-2\%) in their methylation levels [102].

The green tea polyphenol EGCG inhibits DNMTs and reactivates silenced TSG and DNA repair genes ( $p 16$ and $M L H 1$, respectively) through their demethylation in cancer cell lines [73]. Fang et al. also compared the demethylation capacity of EGCG to 5-aza-2'-deoxycytidine and showed that a treatment with $50 \mu \mathrm{M}$ EGCG is comparable to $8.7 \mu \mathrm{M}$ 5-aza-2'-deoxycytidine [73]. The effect of EGCG on the reactivation or demethylation of RASSF1A has not been reported (Table 1). Resveratrol and curcumin function as antioxidants, but also regulate DNMT activity [103]. Resveratrol has been tested for its capacity to reactive TSG in cancer cells $[74,99]$. It has been reported that resveratrol demethylates RASSF1A in women with increased breast cancer risk [74]. Women with an increased breast cancer risk were treated with trans-resveratrol twice a day for 12 weeks. Methylation assessment of four cancer-related genes including RASSF1A was performed on mammary ductoscopy specimens and RASSF1A methylation decreased with increasing levels of serum trans-resveratrol [74].

Curcumin is a polyphenol isolated from turmeric which inhibits DNMT and is a potential chemo-preventive substance [104,105]. It has also been demonstrated that curcumin $(10-20 \mu \mathrm{M}$ for $72 \mathrm{~h}$ ) can enhance the expression level of RASSF1A and decrease its promoter methylation in breast cancer MCF7 cells [76]. Curcumin also reactivates RARB by decreasing its DNA methylation level in lung cancer cell lines [75].

Several polyphenols from the soy bean, including the isoflavones genistein and daidzein, were tested for their capacity to reactivate TSG $[77,78,101]$. It has been shown that these isoflavones regulate DNMT expression or inhibit DNMT activity $[69,101,106]$. In prostate cancer cells the demethylation effects of genistein and daidzein were compared to 5-aza-cytidine for RASSF1A and other hypermethylated promoters [78]. After treatment by soy isoflavones, demethylation of certain promoter regions (GSTP1 and EPHB2) occurred (Table 1), but this was not observed for RASSF1A [78]. Vardi et al. also compared the demethylation capacity of genistein to 5-aza-cytidine in prostate cancer cell lines and showed that $40 \mu \mathrm{M}$ genistein is comparable to $2 \mu \mathrm{M}$ 5-aza-cytidine treatment [78]. Qin et al. treated premenopausal women daily with isoflavones through one menstrual cycle and analyzed the methylation of RASSF1A and other cancer-related genes in intraductal samples [77]. They reported that isoflavones induced dose-specific changes in RARB and CCND2 (cyclin D2) methylation. High genistein levels correlated with increased methylation of RARB and CCND2 [77]. Again, RASSF1A methylation was not significantly affected by this treatment, indicating that genistein is not involved in selective demethylation of the RASSF1A locus (Table 1).

Emodin is a natural polyphenol and anthraquinone derivate from Rheum palmatum [107]. Zhang et al. utilized $40 \mu \mathrm{M}$ emodin to treat pancreatic cancer cells for three days and analyzed the effect on the methylation levels of RASSF1A [80]. They reported the demethylation of RASSF1A, p16 and preproenkepahlin (ppENK) and that emodin downregulates DNMT levels (Table 1). Subsequently they showed that RASSF1A demethylation by $40 \mu \mathrm{M}$ emodin is comparable to $1 \mu \mathrm{M}$ 5-aza-2'-deoxycytidine treatment and RASSF1A demethylation is enhanced by co-treatment with emodin and 5-aza-2'-deoxycytidine [79].

Peperomin $\mathrm{E}$ is another natural polyphenol that has been utilized to study the reactivation of RASSF1A (Table 1). Peperomin E is a bioactive secolignan from the plant peperomia dindygulensis [108]. Peperomin E binds to the active pocket of DNMT1 and reduces DNMT1 levels [81]. Wang et al. treated lung cancer cells with $0.5-2 \mu \mathrm{M}$ peperomin $\mathrm{E}$ for $48 \mathrm{~h}$ and analyzed the methylation and expression of RASSF1A and other TSG [81]. It was shown that the treatment with $2 \mu \mathrm{M}$ of peperomin E resulted in the demethylation and reexpression of RASSF1A, p16, APC and RUNX3 in A549 lung cancer cells [81]. Wang et al. also showed that the treatment with $2 \mu \mathrm{M}$ peperomin $\mathrm{E}$ is comparable to $2 \mu \mathrm{M}$ of 5-aza-2'-deoxycytidine in its demethylation capacity [81]. They propose that peperomin $\mathrm{E}$ 
may serve as a potential chemotherapeutic agent for non-small cell lung cancer, since it also promotes apoptosis and cell cycle arrest [81].

Dioscin is a polyphenolic component isolated from Phyllanthus amarus which exhibits anti-oxidative activity [109]. This substance was utilized to treat bladder cancer cell lines and to analyze its effect on the RASSF1A and DAPK1 expression and methylation [82]. After $48 \mathrm{~h}$ of treatment with 5 and $25 \mu \mathrm{g} / \mathrm{mL}$ dioscin, bladder cancer cells showed induced RASSF1A levels and this increase was correlated with RASSF1A demethylation [82]. However, the impact of dioscin on DNMT expression and activity was not analyzed (Table 1 ).

\title{
7. Effects of Other Natural Compounds on RASSF1A Methylation
}

Mahanine is a carbazole alkaloid from plants (e.g., curry tree/Murraya koenigii) with antioxidative activity [110]. It has also been shown that mahanine inhibits DNMT activity [83,84]. Mahanine $(1-3 \mu \mathrm{g} / \mathrm{mL})$ was utilized to treat cancer cells and to reactive RASSF1A expression. RASSF1A rexpression was observed in prostate, breast and lung cancer cell lines [84,85]. Further data suggest that mahanine is involved in demethylation of the RASSF1A promoter [83].

Phenethyl isothiocyanate (PEITC) is a natural compound from cruciferous vegetables that possesses anti-cancer activities [111]. Boyanapalli et al. treated prostate cancer cells with $5 \mu \mathrm{M}$ PEITC for 5 days and analyzed the RASSF1A methylation and expression levels [86]. They reported that this treatment induced RASSF1A expression by its promoter demethylation (Table 1). Boyanapallli et al. also showed that demethylation of RASSF1A by treatment with $5 \mu \mathrm{M}$ of PEITC is comparable to $2.5 \mu \mathrm{M}$ of 5-aza-2'-deoxycytidine [86]. Furthermore, it was shown that PEITC significantly reduced DNMT1, DNMT3A and DNMT3B protein levels [86]. However, other genomic regions have not been analyzed so far.

\section{Conclusions}

Several natural occurring substances have already been utilized to study their epigenetic activity and to analyze the effect on RASSF1A reactivation (Table 1). The role of methyl donors (e.g., folate and vitamin B12) on the regulation of methylation levels of RASSF1A should be analyzed in further detail and the precise mechanism that modulates this methylation needs to be elucidated. It has also been reported that vitamin A and vitamin D regulate DNMT expression and revert the epigenetic silencing of TSG. Thus it would be interesting to test these substances and others for RASSF1A demethylation and to elucidate the pathways involved in the reactivation process. Several polyphenols, like EGCG and genistein, inhibit DNMT activity and the treatment with these polyphenols lead to demethylation of certain TSG. However, methylation of RASSF1A was not affected by some of these compounds (e.g., genistein). In contrast, conventional demethylating agents such as synthetic cytidine analogues (e.g., 5-aza-2'-deoxycytidine) lead to reactivation of RASSF1A. Mahanine and peperomin $\mathrm{E}$ are also compounds that reactivate RASSF1A by inhibiting DNMT activity. The selective mechanism of some substances (e.g., methyl donors), that on the one hand side promote demethylation of certain TSG but on the other hand cause hypermethylation of other regions (e.g., retrotransponsons), remains enigmatic. Further efforts are needed to address distinct pathways responsible for selective demethylation of TSG like RASSF1A.

Acknowledgments: This work was supported by the German Center for Lung Research (DZL).

Conflicts of Interest: The authors declare no conflict of interest. The founding sponsors had no role in the writing of the manuscript.

\author{
Abbreviations \\ RASSF Ras Association Domain Family \\ TSG tumor suppressor gene \\ DNMT DNA methyltransferase \\ HDAC histone deacetylase \\ EGCG epigalloctechin-3-gallate
}


LINE1 long interspersed nuclear element 1

PEITC phenethyl isothiocyanate

aa

amino acids

\section{References}

1. Iida, T.; Suetake, I.; Tajima, S.; Morioka, H.; Ohta, S.; Obuse, C.; Tsurimoto, T. PCNA clamp facilitates action of DNA cytosine methyltransferase 1 on hemimethylated DNA. Genes Cells 2002, 7, 997-1007. [CrossRef] [PubMed]

2. Sharif, J.; Muto, M.; Takebayashi, S.; Suetake, I.; Iwamatsu, A.; Endo, T.A.; Shinga, J.; Mizutani-Koseki, Y.; Toyoda, T.; Okamura, K.; et al. The SRA protein Np95 mediates epigenetic inheritance by recruiting DNMT1 to methylated DNA. Nature 2007, 450, 908-912. [CrossRef] [PubMed]

3. Richter, A.M.; Pfeifer, G.P.; Dammann, R.H. The RASSF proteins in cancer; from epigenetic silencing to functional characterization. Biochim. Biophys. Acta 2009, 1796, 114-128. [CrossRef] [PubMed]

4. Dammann, R.; Li, C.; Yoon, J.H.; Chin, P.L.; Bates, S.; Pfeifer, G.P. Epigenetic inactivation of a RAS association domain family protein from the lung tumour suppressor locus 3p21.3. Nat. Genet. 2000, 25, 315-319. [PubMed]

5. Sekido, Y.; Ahmadian, M.; Wistuba, I.I.; Latif, F.; Bader, S.; Wei, M.H.; Duh, F.M.; Gazdar, A.F.; Lerman, M.I.; Minna, J.D. Cloning of a breast cancer homozygous deletion junction narrows the region of search for a 3p21.3 tumor suppressor gene. Oncogene 1998, 16, 3151-3157. [CrossRef] [PubMed]

6. Kok, K.; Naylor, S.L.; Buys, C.H. Deletions of the short arm of chromosome 3 in solid tumors and the search for suppressor genes. Adv. Cancer Res. 1997, 71, 27-92. [PubMed]

7. Burbee, D.G.; Forgacs, E.; Zochbauer-Muller, S.; Shivakumar, L.; Fong, K.; Gao, B.; Randle, D.; Kondo, M.; Virmani, A.; Bader, S.; et al. Epigenetic inactivation of RASSF1A in lung and breast cancers and malignant phenotype suppression. J. Natl. Cancer Inst. 2001, 93, 691-699. [CrossRef] [PubMed]

8. Vavvas, D.; Li, X.; Avruch, J.; Zhang, X.F. Identification of Nore1 as a potential Ras effector. J. Biol. Chem. 1998, 273, 5439-5442. [CrossRef] [PubMed]

9. Ortiz-Vega, S.; Khokhlatchev, A.; Nedwidek, M.; Zhang, X.F.; Dammann, R.; Pfeifer, G.P.; Avruch, J. The putative tumor suppressor RASSF1A homodimerizes and heterodimerizes with the Ras-GTP binding protein Nore1. Oncogene 2002, 21, 1381-1390. [CrossRef] [PubMed]

10. Bunney, T.D.; Harris, R.; Gandarillas, N.L.; Josephs, M.B.; Roe, S.M.; Sorli, S.C.; Paterson, H.F.; Rodrigues-Lima, F.; Esposito, D.; Ponting, C.P.; et al. Structural and mechanistic insights into ras association domains of phospholipase C epsilon. Mol. Cell 2006, 21, 495-507. [CrossRef] [PubMed]

11. Scheel, H.; Hofmann, K. A novel interaction motif, SARAH, connects three classes of tumor suppressor. Curr. Biol. CB 2003, 13, R899-R900. [CrossRef] [PubMed]

12. Schagdarsurengin, U.; Richter, A.M.; Hornung, J.; Lange, C.; Steinmann, K.; Dammann, R.H. Frequent epigenetic inactivation of RASSF2 in thyroid cancer and functional consequences. Mol. Cancer 2010, 9, 264. [CrossRef] [PubMed]

13. Guo, C.; Tommasi, S.; Liu, L.; Yee, J.K.; Dammann, R.; Pfeifer, G.P. RASSF1A is part of a complex similar to the Drosophila Hippo/Salvador/Lats tumor-suppressor network. Curr. Biol. CB 2007, 17, 700-705. [CrossRef] [PubMed]

14. Wu, S.; Huang, J.; Dong, J.; Pan, D. hippo encodes a Ste-20 family protein kinase that restricts cell proliferation and promotes apoptosis in conjunction with salvador and warts. Cell 2003, 114, 445-456. [CrossRef]

15. Zhao, B.; Tumaneng, K.; Guan, K.L. The Hippo pathway in organ size control, tissue regeneration and stem cell self-renewal. Nat. Cell Biol. 2011, 13, 877-883. [CrossRef] [PubMed]

16. Sudol, M.; Bork, P.; Einbond, A.; Kastury, K.; Druck, T.; Negrini, M.; Huebner, K.; Lehman, D. Characterization of the mammalian YAP (Yes-associated protein) gene and its role in defining a novel protein module, the WW domain. J. Biol. Chem. 1995, 270, 14733-14741. [CrossRef] [PubMed]

17. Moroishi, T.; Hansen, C.G.; Guan, K.L. The emerging roles of YAP and TAZ in cancer. Nat. Rev. Cancer 2015, 15, 73-79. [CrossRef] [PubMed]

18. Dittfeld, C.; Richter, A.M.; Steinmann, K.; Klagge-Ulonska, A.; Dammann, R.H. The SARAH Domain of RASSF1A and Its Tumor Suppressor Function. Mol. Biol. Int. 2012, 2012. [CrossRef] [PubMed]

19. Jimenez, A.P.; Traum, A.; Boettger, T.; Hackstein, H.; Richter, A.M.; Dammann, R.H. The tumor suppressor RASSF1A induces the YAP1 target gene ANKRD1 that is epigenetically inactivated in human cancers and inhibits tumor growth. Oncotarget 2017. [CrossRef] 
20. Steinmann, K.; Sandner, A.; Schagdarsurengin, U.; Dammann, R.H. Frequent promoter hypermethylation of tumor-related genes in head and neck squamous cell carcinoma. Oncol. Rep. 2009, 22, 1519-1526. [PubMed]

21. Zhang, X.; Guo, C.; Wu, X.; Li, A.X.; Liu, L.; Tsark, W.; Dammann, R.; Shen, H.; Vonderfecht, S.L.; Pfeifer, G.P. Analysis of Liver Tumor-Prone Mouse Models of the Hippo Kinase Scaffold Proteins RASSF1A and SAV1. Cancer Res. 2016, 76, 2824-2835. [CrossRef] [PubMed]

22. Shivakumar, L.; Minna, J.; Sakamaki, T.; Pestell, R.; White, M.A. The RASSF1A tumor suppressor blocks cell cycle progression and inhibits cyclin D1 accumulation. Mol. Cell. Biol. 2002, 22, 4309-4318. [CrossRef] [PubMed]

23. Thaler, S.; Hahnel, P.S.; Schad, A.; Dammann, R.; Schuler, M. RASSF1A mediates p21Cip1/Waf1-dependent cell cycle arrest and senescence through modulation of the Raf-MEK-ERK pathway and inhibition of Akt. Cancer Res. 2009, 69, 1748-1757. [CrossRef] [PubMed]

24. Dammann, R.; Takahashi, T.; Pfeifer, G.P. The CpG island of the novel tumor suppressor gene RASSF1A is intensely methylated in primary small cell lung carcinomas. Oncogene 2001, 20, 3563-3567. [CrossRef] [PubMed]

25. Helmbold, P.; Lahtz, C.; Herpel, E.; Schnabel, P.A.; Dammann, R.H. Frequent hypermethylation of RASSF1A tumour suppressor gene promoter and presence of Merkel cell polyomavirus in small cell lung cancer. Eur. J. Cancer 2009, 45, 2207-2211. [CrossRef] [PubMed]

26. Dammann, R.; Strunnikova, M.; Schagdarsurengin, U.; Rastetter, M.; Papritz, M.; Hattenhorst, U.E.; Hofmann, H.S.; Silber, R.E.; Burdach, S.; Hansen, G. CpG island methylation and expression of tumour-associated genes in lung carcinoma. Eur. J. Cancer 2005, 41, 1223-1236. [CrossRef] [PubMed]

27. Dammann, R.; Yang, G.; Pfeifer, G.P. Hypermethylation of the cpG island of Ras association domain family 1A (RASSF1A), a putative tumor suppressor gene from the 3 p21.3 locus, occurs in a large percentage of human breast cancers. Cancer Res. 2001, 61, 3105-3109. [PubMed]

28. Schagdarsurengin, U.; Wilkens, L.; Steinemann, D.; Flemming, P.; Kreipe, H.H.; Pfeifer, G.P.; Schlegelberger, B.; Dammann, R. Frequent epigenetic inactivation of the RASSF1A gene in hepatocellular carcinoma. Oncogene 2003, 22, 1866-1871. [CrossRef] [PubMed]

29. Dammann, R.; Schagdarsurengin, U.; Liu, L.; Otto, N.; Gimm, O.; Dralle, H.; Boehm, B.O.; Pfeifer, G.P.; Hoang-Vu, C. Frequent RASSF1A promoter hypermethylation and K-ras mutations in pancreatic carcinoma. Oncogene 2003, 22, 3806-3812. [CrossRef] [PubMed]

30. Liu, L.; Yoon, J.H.; Dammann, R.; Pfeifer, G.P. Frequent hypermethylation of the RASSF1A gene in prostate cancer. Oncogene 2002, 21, 6835-6840. [CrossRef] [PubMed]

31. Yoon, J.H.; Dammann, R.; Pfeifer, G.P. Hypermethylation of the CpG island of the RASSF1A gene in ovarian and renal cell carcinomas. Int. J. Cancer 2001, 94, 212-217. [CrossRef] [PubMed]

32. Morrissey, C.; Martinez, A.; Zatyka, M.; Agathanggelou, A.; Honorio, S.; Astuti, D.; Morgan, N.V.; Moch, H.; Richards, F.M.; Kishida, T.; et al. Epigenetic inactivation of the RASSF1A 3p21.3 tumor suppressor gene in both clear cell and papillary renal cell carcinoma. Cancer Res. 2001, 61, 7277-7281. [PubMed]

33. Horiguchi, K.; Tomizawa, Y.; Tosaka, M.; Ishiuchi, S.; Kurihara, H.; Mori, M.; Saito, N. Epigenetic inactivation of RASSF1A candidate tumor suppressor gene at 3p21.3 in brain tumors. Oncogene 2003, 22, 7862-7865. [CrossRef] [PubMed]

34. Byun, D.S.; Lee, M.G.; Chae, K.S.; Ryu, B.G.; Chi, S.G. Frequent epigenetic inactivation of RASSF1A by aberrant promoter hypermethylation in human gastric adenocarcinoma. Cancer Res. 2001, 61, 7034-7038. [PubMed]

35. Dammann, R.; Schagdarsurengin, U.; Seidel, C.; Trumpler, C.; Hoang-Vu, C.; Gimm, O.; Dralle, H.; Pfeifer, G.P.; Brauckhoff, M. Frequent promoter methylation of tumor-related genes in sporadic and men2-associated pheochromocytomas. Exp. Clin. Endocrinol. Diabetes 2005, 113, 1-7. [CrossRef] [PubMed]

36. Schagdarsurengin, U.; Gimm, O.; Hoang-Vu, C.; Dralle, H.; Pfeifer, G.P.; Dammann, R. Frequent epigenetic silencing of the CPG island promoter of RASSF1A in thyroid carcinoma. Cancer Res. 2002, 62, 3698-3701. [PubMed]

37. Chow, L.S.; Lo, K.W.; Kwong, J.; To, K.F.; Tsang, K.S.; Lam, C.W.; Dammann, R.; Huang, D.P. RASSF1A is a target tumor suppressor from 3p21.3 in nasopharyngeal carcinoma. Int. J. Cancer 2004, 109, 839-847. [CrossRef] [PubMed] 
38. Dammann, R.; Schagdarsurengin, U.; Seidel, C.; Strunnikova, M.; Rastetter, M.; Baier, K.; Pfeifer, G.P. The tumor suppressor RASSF1A in human carcinogenesis: An update. Histol. Histopathol. 2005, 20, 645-663. [PubMed]

39. Spugnardi, M.; Tommasi, S.; Dammann, R.; Pfeifer, G.P.; Hoon, D.S. Epigenetic inactivation of RAS association domain family protein 1 (RASSF1A) in malignant cutaneous melanoma. Cancer Res. 2003, 63, 1639-1643. [PubMed]

40. Rastetter, M.; Schagdarsurengin, U.; Lahtz, C.; Fiedler, E.; Marsch, W.; Dammann, R.; Helmbold, P. Frequent intra-tumoural heterogeneity of promoter hypermethylation in malignant melanoma. Histol. Histopathol. 2007, 22, 1005-1015. [PubMed]

41. Helmbold, P.; Lahtz, C.; Enk, A.; Herrmann-Trost, P.; Marsch, W.; Kutzner, H.; Dammann, R.H. Frequent occurrence of RASSF1A promoter hypermethylation and Merkel cell polyomavirus in Merkel cell carcinoma. Mol. Carcinog. 2009, 48, 903-909. [CrossRef] [PubMed]

42. Seidel, C.; Bartel, F.; Rastetter, M.; Bluemke, K.; Wurl, P.; Taubert, H.; Dammann, R. Alterations of cancer-related genes in soft tissue sarcomas: Hypermethylation of RASSF1A is frequently detected in leiomyosarcoma and associated with poor prognosis in sarcoma. Int. J. Cancer 2005, 114, 442-447. [CrossRef] [PubMed]

43. Harada, K.; Toyooka, S.; Maitra, A.; Maruyama, R.; Toyooka, K.O.; Timmons, C.F.; Tomlinson, G.E.; Mastrangelo, D.; Hay, R.J.; Minna, J.D.; et al. Aberrant promoter methylation and silencing of the RASSF1A gene in pediatric tumors and cell lines. Oncogene 2002, 21, 4345-4349. [CrossRef] [PubMed]

44. Kuzmin, I.; Liu, L.; Dammann, R.; Geil, L.; Stanbridge, E.J.; Wilczynski, S.P.; Lerman, M.I.; Pfeifer, G.P. Inactivation of RAS association domain family $1 \mathrm{~A}$ gene in cervical carcinomas and the role of human papillomavirus infection. Cancer Res. 2003, 63, 1888-1893. [PubMed]

45. Avramouli, A.; Tsochas, S.; Mandala, E.; Katodritou, E.; Ioannou, M.; Ritis, K.; Speletas, M. Methylation status of RASSF1A in patients with chronic myeloid leukemia. Leuk. Res. 2009, 33, 1130-1132. [CrossRef] [PubMed]

46. Murray, P.G.; Qiu, G.H.; Fu, L.; Waites, E.R.; Srivastava, G.; Heys, D.; Agathanggelou, A.; Latif, F.; Grundy, R.G.; Mann, J.R.; et al. Frequent epigenetic inactivation of the RASSF1A tumor suppressor gene in Hodgkin's lymphoma. Oncogene 2004, 23, 1326-1331. [CrossRef] [PubMed]

47. Schagdarsurengin, U.; Gimm, O.; Dralle, H.; Hoang-Vu, C.; Dammann, R. CpG island methylation of tumor-related promoters occurs preferentially in undifferentiated carcinoma. Thyroid 2006, 16, 633-642. [CrossRef] [PubMed]

48. Grawenda, A.M.; O'Neill, E. Clinical utility of RASSF1A methylation in human malignancies. Br. J. Cancer 2015, 113, 372-381. [CrossRef] [PubMed]

49. Wang, B.H.; Li, Y.Y.; Han, J.Z.; Zhou, L.Y.; Lv, Y.Q.; Zhang, H.L.; Zhao, L. Gene methylation as a powerful biomarker for detection and screening of non-small cell lung cancer in blood. Oncotarget 2017, 8, 31692-31704. [CrossRef] [PubMed]

50. Strunnikova, M.; Schagdarsurengin, U.; Kehlen, A.; Garbe, J.C.; Stampfer, M.R.; Dammann, R. Chromatin inactivation precedes de novo DNA methylation during the progressive epigenetic silencing of the RASSF1A promoter. Mol. Cell. Biol. 2005, 25, 3923-3933. [CrossRef] [PubMed]

51. Kiehl, S.; Zimmermann, T.; Savai, R.; Pullamsetti, S.S.; Seeger, W.; Bartkuhn, M.; Dammann, R.H. Epigenetic silencing of downstream genes mediated by tandem orientation in lung cancer. Sci. Rep. 2017, 7, 3896. [CrossRef] [PubMed]

52. Moore, D.J.; Onoufriadis, A.; Shoemark, A.; Simpson, M.A.; Zur Lage, P.I.; De Castro, S.C.; Bartoloni, L.; Gallone, G.; Petridi, S.; Woollard, W.J.; et al. Mutations in ZMYND10, a gene essential for proper axonemal assembly of inner and outer dynein arms in humans and flies, cause primary ciliary dyskinesia. Am. J. Hum. Genet. 2013, 93, 346-356. [CrossRef] [PubMed]

53. Gu, S.; Tian, Y.; Chlenski, A.; Salwen, H.R.; Lu, Z.; Raj, J.U.; Yang, Q. Valproic acid shows a potent antitumor effect with alteration of DNA methylation in neuroblastoma. Anticancer Drugs 2012, 23, 1054-1066. [CrossRef] [PubMed]

54. Liu, Y.; Sun, L.; Fong, P.; Yang, J.; Zhang, Z.; Yin, S.; Jiang, S.; Liu, X.; Ju, H.; Huang, L.; et al. An association between overexpression of DNA methyltransferase 3B4 and clear cell renal cell carcinoma. Oncotarget 2017, 8, 19712-19722. [CrossRef] [PubMed] 
55. Palakurthy, R.K.; Wajapeyee, N.; Santra, M.K.; Gazin, C.; Lin, L.; Gobeil, S.; Green, M.R. Epigenetic silencing of the RASSF1A tumor suppressor gene through HOXB3-mediated induction of DNMT3B expression. Mol. Cell 2009, 36, 219-230. [CrossRef] [PubMed]

56. Soejima, K.; Fang, W.; Rollins, B.J. DNA methyltransferase 3b contributes to oncogenic transformation induced by SV40T antigen and activated Ras. Oncogene 2003, 22, 4723-4733. [CrossRef] [PubMed]

57. Momparler, R.L. Epigenetic therapy of cancer with 5-aza-2'-deoxycytidine (decitabine). Semin. Oncol. 2005, 32, 443-451. [CrossRef] [PubMed]

58. Ren, J.; Singh, B.N.; Huang, Q.; Li, Z.; Gao, Y.; Mishra, P.; Hwa, Y.L.; Li, J.; Dowdy, S.C.; Jiang, S.W. DNA hypermethylation as a chemotherapy target. Cell Signal. 2011, 23, 1082-1093. [CrossRef] [PubMed]

59. Issa, J.P.; Kantarjian, H.M.; Kirkpatrick, P. Azacitidine. Nat. Rev. Drug Discov. 2005, 4, 275-276. [CrossRef] [PubMed]

60. Flotho, C.; Claus, R.; Batz, C.; Schneider, M.; Sandrock, I.; Ihde, S.; Plass, C.; Niemeyer, C.M.; Lubbert, M. The DNA methyltransferase inhibitors azacitidine, decitabine and zebularine exert differential effects on cancer gene expression in acute myeloid leukemia cells. Leukemia 2009, 23, 1019-1028. [CrossRef] [PubMed]

61. Kaminskas, E.; Farrell, A.T.; Wang, Y.C.; Sridhara, R.; Pazdur, R. FDA drug approval summary: Azacitidine (5-azacytidine, Vidaza) for injectable suspension. Oncologist 2005, 10, 176-182. [CrossRef] [PubMed]

62. Hackanson, B.; Daskalakis, M. Decitabine. Recent Results Cancer Res. 2014, 201, 269-297. [PubMed]

63. Kantarjian, H.M.; Roboz, G.J.; Kropf, P.L.; Yee, K.W.L.; O'Connell, C.L.; Tibes, R.; Walsh, K.J.; Podoltsev, N.A.; Griffiths, E.A.; Jabbour, E.; et al. Guadecitabine (SGI-110) in treatment-naive patients with acute myeloid leukaemia: Phase 2 results from a multicentre, randomised, phase 1/2 trial. Lancet Oncol. 2017, 18, 1317-1326. [CrossRef]

64. Foulks, J.M.; Parnell, K.M.; Nix, R.N.; Chau, S.; Swierczek, K.; Saunders, M.; Wright, K.; Hendrickson, T.F.; Ho, K.K.; McCullar, M.V.; et al. Epigenetic drug discovery: Targeting DNA methyltransferases. J. Biomol. Screen. 2012, 17, 2-17. [CrossRef] [PubMed]

65. Fang, F.; Munck, J.; Tang, J.; Taverna, P.; Wang, Y.; Miller, D.F.; Pilrose, J.; Choy, G.; Azab, M.; Pawelczak, K.S.; et al. The novel, small-molecule DNA methylation inhibitor SGI-110 as an ovarian cancer chemosensitizer. Clin. Cancer Res. 2014, 20, 6504-6516. [CrossRef] [PubMed]

66. Balch, C.; Yan, P.; Craft, T.; Young, S.; Skalnik, D.G.; Huang, T.H.; Nephew, K.P. Antimitogenic and chemosensitizing effects of the methylation inhibitor zebularine in ovarian cancer. Mol. Cancer Ther. 2005, 4, 1505-1514. [CrossRef] [PubMed]

67. Lemaire, M.; Momparler, L.F.; Raynal, N.J.; Bernstein, M.L.; Momparler, R.L. Inhibition of cytidine deaminase by zebularine enhances the antineoplastic action of 5-aza-2'-deoxycytidine. Cancer Chemother. Pharmacol. 2009, 63, 411-416. [CrossRef] [PubMed]

68. Zwergel, C.; Valente, S.; Mai, A. DNA Methyltransferases Inhibitors from Natural Sources. Curr. Top. Med. Chem. 2016, 16, 680-696. [CrossRef] [PubMed]

69. Stefanska, B.; Karlic, H.; Varga, F.; Fabianowska-Majewska, K.; Haslberger, A. Epigenetic mechanisms in anti-cancer actions of bioactive food components-The implications in cancer prevention. Br. J. Pharmacol. 2012, 167, 279-297. [CrossRef] [PubMed]

70. Ottini, L.; Rizzolo, P.; Siniscalchi, E.; Zijno, A.; Silvestri, V.; Crebelli, R.; Marcon, F. Gene promoter methylation and DNA repair capacity in monozygotic twins with discordant smoking habits. Mutat. Res. Genet. Toxicol. Environ. Mutagen. 2015, 779, 57-64. [CrossRef] [PubMed]

71. Pirouzpanah, S.; Taleban, F.A.; Mehdipour, P.; Atri, M. Association of folate and other one-carbon related nutrients with hypermethylation status and expression of RARB, BRCA1, and RASSF1A genes in breast cancer patients. J. Mol. Med. 2015, 93, 917-934. [CrossRef] [PubMed]

72. Vineis, P.; Chuang, S.C.; Vaissiere, T.; Cuenin, C.; Ricceri, F.; Genair, E.C.; Johansson, M.; Ueland, P.; Brennan, P.; Herceg, Z. DNA methylation changes associated with cancer risk factors and blood levels of vitamin metabolites in a prospective study. Epigenetics 2011, 6, 195-201. [CrossRef] [PubMed]

73. Fang, M.Z.; Wang, Y.; Ai, N.; Hou, Z.; Sun, Y.; Lu, H.; Welsh, W.; Yang, C.S. Tea polyphenol (-)-epigallocatechin-3-gallate inhibits DNA methyltransferase and reactivates methylation-silenced genes in cancer cell lines. Cancer Res. 2003, 63, 7563-7570. [PubMed]

74. Zhu, W.; Qin, W.; Zhang, K.; Rottinghaus, G.E.; Chen, Y.C.; Kliethermes, B.; Sauter, E.R. Trans-resveratrol alters mammary promoter hypermethylation in women at increased risk for breast cancer. Nutr. Cancer 2012, 64, 393-400. [CrossRef] [PubMed] 
75. Jiang, A.; Wang, X.; Shan, X.; Li, Y.; Wang, P.; Jiang, P.; Feng, Q. Curcumin Reactivates Silenced Tumor Suppressor Gene RARbeta by Reducing DNA Methylation. Phytother. Res. 2015, 29, 1237-1245. [CrossRef] [PubMed]

76. Du, L.; Xie, Z.; Wu, L.C.; Chiu, M.; Lin, J.; Chan, K.K.; Liu, S.; Liu, Z. Reactivation of RASSF1A in breast cancer cells by curcumin. Nutr. Cancer 2012, 64, 1228-1235. [CrossRef] [PubMed]

77. Qin, W.; Zhu, W.; Shi, H.; Hewett, J.E.; Ruhlen, R.L.; MacDonald, R.S.; Rottinghaus, G.E.; Chen, Y.C.; Sauter, E.R. Soy isoflavones have an antiestrogenic effect and alter mammary promoter hypermethylation in healthy premenopausal women. Nutr. Cancer 2009, 61, 238-244. [CrossRef] [PubMed]

78. Vardi, A.; Bosviel, R.; Rabiau, N.; Adjakly, M.; Satih, S.; Dechelotte, P.; Boiteux, J.P.; Fontana, L.; Bignon, Y.J.; Guy, L.; et al. Soy phytoestrogens modify DNA methylation of GSTP1, RASSF1A, EPH2 and BRCA1 promoter in prostate cancer cells. In Vivo 2010, 24, 393-400. [PubMed]

79. Pan, F.P.; Zhou, H.K.; Bu, H.Q.; Chen, Z.Q.; Zhang, H.; Xu, L.P.; Tang, J.; Yu, Q.J.; Chu, Y.Q.; Pan, J.; et al. Emodin enhances the demethylation by 5-Aza-CdR of pancreatic cancer cell tumor-suppressor genes P16, RASSF1A and ppENK. Oncol. Rep. 2016, 35, 1941-1949. [CrossRef] [PubMed]

80. Zhang, H.; Chen, L.; Bu, H.Q.; Yu, Q.J.; Jiang, D.D.; Pan, F.P.; Wang, Y.; Liu, D.L.; Lin, S.Z. Effects of emodin on the demethylation of tumor-suppressor genes in pancreatic cancer PANC-1 cells. Oncol. Rep. 2015, 33, 3015-3023. [CrossRef] [PubMed]

81. Wang, X.Z.; Cheng, Y.; Wang, K.L.; Liu, R.; Yang, X.L.; Wen, H.M.; Chai, C.; Liang, J.Y.; Wu, H. Peperomin E reactivates silenced tumor suppressor genes in lung cancer cells by inhibition of DNA methyltransferase. Cancer Sci. 2016, 107, 1506-1519. [CrossRef] [PubMed]

82. Zhou, Q.; Song, W.; Xiao, W. Dioscin induces demethylation of DAPK-1 and RASSF-1alpha genes via the antioxidant capacity, resulting in apoptosis of bladder cancer T24 cells. EXCLI J. 2017, 16, 101-112. [PubMed]

83. Agarwal, S.; Amin, K.S.; Jagadeesh, S.; Baishay, G.; Rao, P.G.; Barua, N.C.; Bhattacharya, S.; Banerjee, P.P. Mahanine restores RASSF1A expression by down-regulating DNMT1 and DNMT3B in prostate cancer cells. Mol. Cancer 2013, 12, 99. [CrossRef] [PubMed]

84. Jagadeesh, S.; Sinha, S.; Pal, B.C.; Bhattacharya, S.; Banerjee, P.P. Mahanine reverses an epigenetically silenced tumor suppressor gene RASSF1A in human prostate cancer cells. Biochem. Biophys. Res. Commun. 2007, 362, 212-217. [CrossRef] [PubMed]

85. Sheikh, K.D.; Banerjee, P.P.; Jagadeesh, S.; Grindrod, S.C.; Zhang, L.; Paige, M.; Brown, M.L. Fluorescent epigenetic small molecule induces expression of the tumor suppressor ras-association domain family $1 \mathrm{~A}$ and inhibits human prostate xenograft. J. Med. Chem. 2010, 53, 2376-2382. [CrossRef] [PubMed]

86. Boyanapalli, S.S.; Li, W.; Fuentes, F.; Guo, Y.; Ramirez, C.N.; Gonzalez, X.P.; Pung, D.; Kong, A.N. Epigenetic reactivation of RASSF1A by phenethyl isothiocyanate (PEITC) and promotion of apoptosis in LNCaP cells. Pharmacol. Res. 2016, 114, 175-184. [CrossRef] [PubMed]

87. Shorter, K.R.; Felder, M.R.; Vrana, P.B. Consequences of dietary methyl donor supplements: Is more always better? Prog. Biophys. Mol. Biol. 2015, 118, 14-20. [CrossRef] [PubMed]

88. Anderson, O.S.; Sant, K.E.; Dolinoy, D.C. Nutrition and epigenetics: An interplay of dietary methyl donors, one-carbon metabolism and DNA methylation. J. Nutr. Biochem. 2012, 23, 853-859. [CrossRef] [PubMed]

89. Waterland, R.A.; Jirtle, R.L. Transposable elements: Targets for early nutritional effects on epigenetic gene regulation. Mol. Cell. Biol. 2003, 23, 5293-5300. [CrossRef] [PubMed]

90. Xu, X.; Gammon, M.D.; Jefferson, E.; Zhang, Y.; Cho, Y.H.; Wetmur, J.G.; Teitelbaum, S.L.; Bradshaw, P.T.; Terry, M.B.; Garbowski, G.; et al. The influence of one-carbon metabolism on gene promoter methylation in a population-based breast cancer study. Epigenetics 2011, 6, 1276-1283. [CrossRef] [PubMed]

91. Van Engeland, M.; Weijenberg, M.P.; Roemen, G.M.; Brink, M.; De Bruine, A.P.; Goldbohm, R.A.; Van den Brandt, P.A.; Baylin, S.B.; De Goeij, A.F.; Herman, J.G. Effects of dietary folate and alcohol intake on promoter methylation in sporadic colorectal cancer: The Netherlands cohort study on diet and cancer. Cancer Res. 2003, 63, 3133-3137. [PubMed]

92. Vaissiere, T.; Hung, R.J.; Zaridze, D.; Moukeria, A.; Cuenin, C.; Fasolo, V.; Ferro, G.; Paliwal, A.; Hainaut, P.; Brennan, P.; et al. Quantitative analysis of DNA methylation profiles in lung cancer identifies aberrant DNA methylation of specific genes and its association with gender and cancer risk factors. Cancer Res. 2009, 69, 243-252. [CrossRef] [PubMed]

93. Nazki, F.H.; Sameer, A.S.; Ganaie, B.A. Folate: Metabolism, genes, polymorphisms and the associated diseases. Gene 2014, 533, 11-20. [CrossRef] [PubMed] 
94. Cai, D.W.; Liu, X.F.; Bu, R.G.; Chen, X.N.; Ning, L.; Cheng, Y.; Wu, B. Genetic polymorphisms of MTHFR and aberrant promoter hypermethylation of the RASSF1A gene in bladder cancer risk in a Chinese population. J. Int. Med. Res. 2009, 37, 1882-1889. [CrossRef] [PubMed]

95. Coppede, F.; Migheli, F.; Lopomo, A.; Failli, A.; Legitimo, A.; Consolini, R.; Fontanini, G.; Sensi, E.; Servadio, A.; Seccia, M.; et al. Gene promoter methylation in colorectal cancer and healthy adjacent mucosa specimens: Correlation with physiological and pathological characteristics, and with biomarkers of one-carbon metabolism. Epigenetics 2014, 9, 621-633. [CrossRef] [PubMed]

96. Supic, G.; Jovic, N.; Kozomara, R.; Zeljic, K.; Magic, Z. Interaction between the MTHFR C677T polymorphism and alcohol-impact on oral cancer risk and multiple DNA methylation of tumor-related genes. J. Dent. Res. 2011, 90, 65-70. [CrossRef] [PubMed]

97. Premkumar, V.G.; Yuvaraj, S.; Shanthi, P.; Sachdanandam, P. Co-enzyme Q10, riboflavin and niacin supplementation on alteration of DNA repair enzyme and DNA methylation in breast cancer patients undergoing tamoxifen therapy. Br. J. Nutr. 2008, 100, 1179-1182. [CrossRef] [PubMed]

98. Fazi, F.; Travaglini, L.; Carotti, D.; Palitti, F.; Diverio, D.; Alcalay, M.; McNamara, S.; Miller, W.H., Jr.; Lo Coco, F.; Pelicci, P.G.; et al. Retinoic acid targets DNA-methyltransferases and histone deacetylases during APL blast differentiation in vitro and in vivo. Oncogene 2005, 24, 1820-1830. [CrossRef] [PubMed]

99. Stefanska, B.; Salame, P.; Bednarek, A.; Fabianowska-Majewska, K. Comparative effects of retinoic acid, vitamin D and resveratrol alone and in combination with adenosine analogues on methylation and expression of phosphatase and tensin homologue tumour suppressor gene in breast cancer cells. Br. J. Nutr. 2012, 107, 781-790. [CrossRef] [PubMed]

100. Fang, M.; Chen, D.; Yang, C.S. Dietary polyphenols may affect DNA methylation. J. Nutr. 2007, 137, $223 \mathrm{~S}-228 \mathrm{~S}$. [PubMed]

101. Mirza, S.; Sharma, G.; Parshad, R.; Gupta, S.D.; Pandya, P.; Ralhan, R. Expression of DNA methyltransferases in breast cancer patients and to analyze the effect of natural compounds on DNA methyltransferases and associated proteins. J. Breast Cancer 2013, 16, 23-31. [CrossRef] [PubMed]

102. Scoccianti, C.; Ricceri, F.; Ferrari, P.; Cuenin, C.; Sacerdote, C.; Polidoro, S.; Jenab, M.; Hainaut, P.; Vineis, P.; Herceg, Z. Methylation patterns in sentinel genes in peripheral blood cells of heavy smokers: Influence of cruciferous vegetables in an intervention study. Epigenetics 2011, 6, 1114-1119. [CrossRef] [PubMed]

103. Singh, V.; Sharma, P.; Capalash, N. DNA methyltransferase-1 inhibitors as epigenetic therapy for cancer. Curr. Cancer Drug Targets 2013, 13, 379-399. [CrossRef] [PubMed]

104. Campbell, F.C.; Collett, G.P. Chemopreventive properties of curcumin. Future Oncol. 2005, 1, 405-414. [CrossRef] [PubMed]

105. Shu, L.; Khor, T.O.; Lee, J.H.; Boyanapalli, S.S.; Huang, Y.; Wu, T.Y.; Saw, C.L.; Cheung, K.L.; Kong, A.N. Epigenetic $\mathrm{CPG}$ demethylation of the promoter and reactivation of the expression of Neurog1 by curcumin in prostate LNCaP cells. AAPS J. 2011, 13, 606-614. [CrossRef] [PubMed]

106. Li, H.; Xu, W.; Huang, Y.; Huang, X.; Xu, L.; Lv, Z. Genistein demethylates the promoter of CHD5 and inhibits neuroblastoma growth in vivo. Int. J. Mol. Med. 2012, 30, 1081-1086. [CrossRef] [PubMed]

107. Huang, Q.; Lu, G.; Shen, H.M.; Chung, M.C.; Ong, C.N. Anti-cancer properties of anthraquinones from rhubarb. Med. Res. Rev. 2007, 27, 609-630. [CrossRef] [PubMed]

108. Wu, J.L.; Li, N.; Hasegawa, T.; Sakai, J.; Mitsui, T.; Ogura, H.; Kataoka, T.; Oka, S.; Kiuchi, M.; Tomida, A.; et al. Bioactive secolignans from Peperomia dindygulensis. J. Nat. Prod. 2006, 69, 790-794. [CrossRef] [PubMed]

109. Wang, Z.; Cheng, Y.; Wang, N.; Wang, D.M.; Li, Y.W.; Han, F.; Shen, J.G.; Yang, D.P.; Guan, X.Y.; Chen, J.P. Dioscin induces cancer cell apoptosis through elevated oxidative stress mediated by downregulation of peroxiredoxins. Cancer Biol. Ther. 2012, 13, 138-147. [PubMed]

110. Tachibana, Y.; Kikuzaki, H.; Lajis, N.H.; Nakatani, N. Antioxidative activity of carbazoles from Murraya koenigii leaves. J. Agric. Food Chem. 2001, 49, 5589-5594. [CrossRef] [PubMed]

111. Gupta, P.; Wright, S.E.; Kim, S.H.; Srivastava, S.K. Phenethyl isothiocyanate: A comprehensive review of anti-cancer mechanisms. Biochim. Biophys. Acta 2014, 1846, 405-424. [CrossRef] [PubMed]

(C) 2017 by the authors. Licensee MDPI, Basel, Switzerland. This article is an open access article distributed under the terms and conditions of the Creative Commons Attribution (CC BY) license (http:/ / creativecommons.org/licenses/by/4.0/). 